\title{
UNGKAPAN FATIS PEMBUKA DAN PENUTUP PERCAKAPAN MASYARAKAT JAWA DI SURAKARTA
}

\author{
Ratna Susanti \\ ratnasusanti19@yahoo.co.id \\ Dewi Agustini \\ dwtini@gmail.com \\ Politeknik Indonusa Surakarta
}

\begin{abstract}
Good, true, and polite personality expressions reflect one's noble character. The use of the phrase when one is expressing the intent to others, should be conveyed in polite form. This politeness is reflected in the use of expressions in communication. This research aimed to identify the forms, use, and local wisdom of expression phatic opening and closing the conversation in the Java community, especially in the area of Surakarta. The research shows that variations in the forms of expression of phatic. This expression aims to start a conversation, ask permission, refine the command, grateful, subtle rejection, words of sympathy, and apologized. The result showed that in order to establish harmony in their interaction in the community and as a form of politeness, found various expressions phatic in the Java community, especially in the area of Surakarta is an expression sugeng rawuh, kula nuwun, matur nuwun, nyuwun tulung, nyuwun pangapunten, mangga, kados pundi, sugeng ...atau wilujeng ..., katuran pinarak, ndherek bingah, and ndherek belasungkawa.
\end{abstract}

Keywords: phatic expression, modesty local wisdom, Java community

\section{Pendahuluan}

Pentingnya

bahasa dalam kehidupan manusia ini dipertegas oleh Wijana \& Rohmadi (2006, 11), bahwa berbahasa itu seperti orang bernapas yang tidak pernah terpikirkan. Menurut Nababan, manusia menggunakan bahasa tatkala dalam kondisi bangun (sadar) dan dalam kondisi tidur pun manusia menggunakan bahasa. Bahasa memegang peranan penting dalam proses komunikasi. Peran tersebut akan mampu memainkan fungsinya jika dalam tuturan akan tercipta komunikasi yang baik. Kegiatan bertutur selalu melibatkan dua hal utama, yaitu penutur (komunikator) dan mitra tutur (komunikan). Kegiatan bertutur pada dasarnya akan selalu hadir di tengah-tengah masyarakat. Hal ini dikarenakan kegiatan bertutur merupakan sarana berinteraksi masyarakat satu dengan lainnya.
Mengingat pentingnya peranan bahasa dalam berkomunikasi, Jacobson \& Gottman (2004, 81) kemudian membagi fungsi bahasa menjadi fungsi referensial, fungsi emotif, fungsi konatif, fungsi metalingual, fungsi fatis, dan fungsi puitis.

Komunikasi fatis, sebagaimana diungkapkan oleh Malinowski (1993, 299), bertujuan untuk menjaga keakraban dan kesantunan, misalnya bertanya kesehatan, bertanya asal, komentar tentang cuaca, dan menegaskan sesuatu yang sudah jelas. Contoh ungkapan: How do you do?, Here you are, Where do you come from?, dan Nice day today. Bentuk-bentuk ungkapan tersebut tidak untuk memberikan informasi dan juga tidak untuk menyampaikan ide atau gagasan.

Dalam masyarakat Jawa, khususnya di wilayah Surakarta, yang meliputi Klaten, Sukoharjo, Boyolali, dan Sragen pun dikenal beberapa 
bentuk ungkapan fatis yang bertujuan untuk mengungkapkan kesantunan dan sosiabilitas, misalnya ungkapan matur nuwun, nyuwun sewu, nderek pirsa, nyuwun pangapunten, kula nuwun, dan sebagainya. Bentuk-bentuk ungkapan tersebut memiliki fungsi fatis yang bertujuan untuk menjaga kesantunan

Untuk mengetahui bagaimana bentuk ungkapan fatis sebagai sarana kesopanan dalam berkomunikasi pada masyarakat Jawa, khususnya di wilayah Surakarta, diperlukan kajian yang melibatkan pemahaman akan nilai budaya dan situasi tutur dan pandangan hidup orang Jawa. Oleh karena itu, dalam penelitian dibahas beberapa ungkapan fatis dalam masyarakat Jawa, khususnya dalam pembuka dan penutup percakapan.

Oleh karena itu, dalam penelitian ini dirumuskan permasalahan sebagai berikut.

1. Bagaimana bentuk-bentuk ungkapan fatis pembuka dan penutup percakapan dalam masyarakat Jawa, khususnya di wilayah Surakarta?

2. Bagaimana penggunaan bentukbentuk ungkapan fatis pembuka dan penutup dalam masyarakat Jawa, khususnya di wilayah Surakarta?

3. Bagaimana makna pandangan hidup masyarakat Jawa, khususnya di wilayah Surakarta, yang tecermin dalam bentuk-bentuk ungkapan fatis pembuka dan penutup percakapan?

\section{Tinjauan Pustaka Tindak Tutur}

Teori tindak tutur pertama kali diungkapkan oleh Austin (1955), seorang ahli filsafat senior dari Inggris, yang kemudian dikembangkan dan dipopulerkan secara universal oleh muridnya bernama Searle (1969). Menurut Searle, setiap komunikasi terdapat tindak tutur. Tindak tutur (speech act) menurut Austin, di dalam mengutarakan tuturan, seseorang dapat melakukan sesuatu selain mengatakan sesuatu. Misalnya, "Saya mohon maaf atas keterlambatan saya." Contoh tuturan tersebut dipergunakan untuk melakukan tindakan, yaitu meminta maaf.

\section{Komunikasi Fatis dan Kesantunan}

Tuturan fatis adalah suatu bentuk tuturan yang digunakan untuk memulai, mempertahankan, atau mengukuhkan komunikasi antara pembicara dan lawan bicara. Bentuk tuturan fatis dapat berupa pertanyaanpertanyaan yang tidak informatif dalam komunikasi, akan tetapi pertanyaan tersebut sangat penting dilakukan demi menjaga komunikasi supaya terus berlangsung (Kridalaksana 2000, 114).

Ungkapan fatis merupakan bentuk tindak tutur yang berfungsi menjalin hubungan sosial. Tujuannya adalah untuk membangun solidaritas antaranggota dari lingkungannya. Bentuk ungkapan fatis, di antaranya, salam, ucapan perpisahan, ucapanucapan kesantunan, seperti "Terima kasih kembali", "Maafkan saya", hal itu memiliki tujuan tertentu.

Penggunaan kategori fatis dalam bentuk ungkapan, misalnya (1) ucapan selamat, contoh "Selamat pagi", (2) ucapan "Terima kasih", (3) ucapan salam berupa "Assalamualaikum dan Waalaikumsalam" untuk membuka dan menutup komunikasi. Ucapan salam selain digunakan untuk membuka dan menutup komunikasi, juga digunakan untuk mengungkapkan kesantunan (memertahankan jarak sosial) dan persahabatan (menghilangkan jarak sosial) dengan mitra tutur.

Malinowski (1993) mengungkap-kan lebih lanjut beberapa ciri bentuk kefatisan adalah sebagai berikut: (1) memecahkan kesenyapan, (2) tidak bersifat informatif, (3) mengomentari sesuatu yang sudah jelas, dan (4) menciptakan ikatan sosial yang 
harmonis dengan semata-mata bertukar kata.

Dalam penelitian ini, penulis membatasi bentuk kefatisan bahasa yang berfungsi untuk membuka dan menutup percakapan dalam masyarakat Jawa, khususnya di wilayah Surakarta.

\section{Prinsip Kesantunan Berbahasa}

Kesantunan, sebagaimana disebutkan dalam Kamus Besar Bahasa Indonesia (KBBI) Edisi Keempat, adalah kehalusan dan budi (budi bahasa dan tingkah laku). Kesantunan merupakan aturan perilaku yang ditetapkan dan disepakati bersama oleh suatu masyarakat tertentu sehingga kesantunan sekaligus menjadi prasyarat yang disepakati oleh perilaku sosial. Oleh karena itu, kesantunan ini biasa disebut tata krama. Kesantunan bersifat relatif di dalam masyarakat. Ujaran tertentu bisa dikatakan santun di dalam suatu kelompok masyarakat tertentu, akan tetapi di kelompok masyarakat lain bisa dikatakan tidak santun. Kesantunan merupakan fenomena kultural, sehingga apa yang dianggap santun oleh suatu kultur mungkin tidak demikian halnya dengan kultur yang lain. Tujuan kesantunan, termasuk kesantunan berbahasa, adalah membuat suasana berinteraksi menyenangkan, tidak mengancam muka dan efektif.

Menurut Rahardi (2005, 35) penelitian kesantunan mengkaji penggunaan bahasa (language use) dalam suatu masyarakat bahasa tertentu. Masyarakat bahasa yang dimaksud adalah masyarakat dengan aneka latar belakang situasi sosial dan budaya yang mewadahinya. Adapun yang dikaji di dalam penelitian kesantunan adalah segi maksud dan fungsi tuturan. Fraser (melalui Rahardi 2005, 38-40) menyebutkan bahwa sedikitnya terdapat empat pandangan yang dapat digunakan untuk mengkaji masalah kesantunan dalam bertutur.

1. Pandangan kesantunan yang berkaitan dengan norma-norma sosial (the social-norm view). Dalam pandangan ini, kesantunan dalam bertutur ditentukan berdasarkan norma-norma sosial dan kultural yang ada dan berlaku di dalam masyarakat bahasa itu. Santun dalam bertutur ini disejajarkan dengan etiket berbahasa (language etiquette).

2. Pandangan yang melihat kesantunan sebagai sebuah maksim percakapan (conver-sational maxim) dan sebagai sebuah upaya penyelamatan muka (face saving).

3. Pandangan kesantunan sebagai maksim percakapan menganggap prinsip kesantunan (politeness principle) hanyalah sebagai pelengkap prinsip kerja sama (cooperative principle).

4. Pandangan yang melihat kesantunan sebagai tindakan untuk memenuhi persyaratan terpenuhinya sebuah kontrak percakapan (conversational contract).

Jadi, bertindak santun itu sejajar dengan bertutur yang penuh pertimbangan etiket berbahasa. Kesantunan berbahasa tercermin dalam tatacara berkomunikasi lewat tanda verbal atau tatacara berbahasa. Ketika berkomunikasi, kita tunduk pada norma-norma budaya, tidak hanya sekedar menyampaikan ide yang kita pikirkan. Tata cara berbahasa harus sesuai dengan norma budaya yang ada dalam masyarakat tempat hidup dan dipergunakannya suatu bahasa dalam berkomunikasi. Apabila tatacara berbahasa seseorang tidak sesuai dengan norma-norma budaya, maka ia akan mendapatkan nilai negatif, misalnya dituduh sebagai orang yang sombong, angkuh, tak acuh, egois, tidak beradat, bahkan tidak berbudaya.

Kesantunan berbahasa dapat dilakukan dengan cara pelaku tutur mematuhi prinsip santun berbahasa yang berlaku di masyarakat pemakai bahasa itu. Jadi, diharapkan pelaku tutur dalam bertutur dengan mitra 
tuturnya untuk tidak mengabaikan prinsip kesantunan. Hal ini untuk menjaga hubungan baik dengan mitra tuturnya.

Untuk menjaga kesantunan, Leech (2003) mengemukakan enam maksim dalam prinsip kesantunan yaitu maksim kebijaksanaan, maksim kemurahan hati, maksim penerimaan, maksim kerendahan hati, maksim kecocokan, dan maksim simpati. Maksim ini berfungsi untuk menjaga kesantunan sebuah tuturan.

Maksim pertama adalah maksim kebijaksanaan. Sebuah tuturan dikatakan memenuhi maksim kebijaksanaan apabila tuturan tersebut memberikan keuntungan pada mitra tutur. Dengan mematuhi maksim kebijaksanaan, penutur dapat menghindari sikap dengki dan kurang santun kepada mitra tutur. Menurut maksim ini semakin panjang tuturan semakin besar juga keinginan penutur untuk bersikap santun kepada mitra tuturnya.

Maksim kedua adalah maksim kedermawanan. Dalam menerapkan maksim kemurahatian atau kedermawanan tersebut hal yang harus dilakukan adalah menuntut setiap penutur dan mitra tutur untuk memaksimalkan rasa hormat kepada orang lain dan meminimalkan rasa tidak hormat kepada orang lain. Maksim ketiga adalah maksim penerimaan atau maksim penghargaan, yaitu maksim yang mempunyai prinsip kurangi cacian pada orang lain dan tambahi pujian pada orang lain.

Selanjutnya, maksim kerendahan hati atau maksim kesederhanaan. Maksim ini memiliki prinsip berupa kurangi pujian pada diri sendiri dan tambahi cacian pada diri sendiri. Informasi ini mengandung pengertian bahwa tuturan seorang penutur akan dianggap bernilai sopan santun apabila penutur benar-benar mampu menempatkan diri secara tepat. Artinya, penutur tidak terfokus untuk membicarakan diri sendiri, tidak pamer, yang pada akhirnya memberikan pujian yang berlebihan kepada diri sendiri. Hal yang lebih mendasar dan nilai kesantunan berbahasa ini dapat tercapai dengan prinsip kesederhanaan apabila penutur juga mampu 'mencaci' diri sendiri, menempatkan diri sebagai makhluk Tuhan yang tentunya lengkap dengan kekurangan dan kelebihan.

Maksim kecocokan atau maksim permufakatan. Prinsip permufakatan mempunyai landasan pemikiran perlunya mengurangi ketidaksesuaian antara diri sendiri dengan orang lain. Tingkatan persesuaian antara diri sendiri dengan orang lain. Maksim keenam adalah maksim simpati. Prinsip ini dilakukan dengan cara kurangi antipati antara diri sendiri dengan orang lain dan perbesar simpati antara diri sendiri dengan orang lain (Tarigan, 1990).

\section{Kearifan Lokal dan Nilai Budaya dalam Ungkapan Fatis}

Kearifan lokal menurut Wales dalam Poespowardojo (2000, 30) adalah "the sum of cultural characteristics which the vast majority of people have in common as a result of their experiences in early life." Definisi tersebut dapat dikatakan bahwa local genius ditandai oleh (1) karakteristik budaya atau cirri-ciri keseluruhan, (2) sekelompok manusia sebagai penganut budaya tersebut, (3) pengalaman hidup menghasilkan ciri-ciri budaya.

Kearifan lokal atau local genius lahir dari sekelompok etnis tertentu yang diperoleh dari pengalaman dalam kehidupannya. Selanjutnya diwariskan dari satu generasi ke generasi lainnya melalui bahasa mereka. Ungkapan fatis sebagai salah satu bentuk unik bahasa etnis tertentu merupakan warisan nenek moyang yang mengandung nilainilai kearifan lokal dari penutur tertentu karena di dalamnya termuat prinsip-prinsip kesopanan untuk dijadikan sebagai pedoman hidup. 


\section{Penelitian Terdahulu}

Suharyo(2013) dalam penelitiannya yang berjudul Ungkapan Fatis dalam Bahasa Indonesia Ragam Nonformal menyatakan bahwa dalam terminologi linguistik, kondisi peneguhan pentingnya bahasa dalam interaksi antarpeserta tutur mendapatkan signifikansinya ketika berfungsi sebagai alat untuk membuka saluran komunikasi, mengakrabkan, 'menyatukan (hati)', antara penutur dan peserta tutur disebut kategori fatis. Kategori fatis dalam tuturan tampaknya lebih banyak muncul pada tuturan bahasa Indoensia ragam nonformal, misalnya pada acara radio dan televisi. Untuk mendeskripsikan penggunaan kategori fatis dalam penelitian awal ini digunakan metode simak, teknik rekam, dan teknik catat untuk menggali data terhadap objek kajian berupa tuturan bahasa Indonesia ragam nonformal di radio dan terutama di televisi. Acara yang dijadikan sumber data, misalnya Inbox, Dahsyat, 100\% Ampuh; sedangkan metode informal digunakan untuk teknik penyajian. Dari hasil penelitian ditemukan bahwa bentuk ungkapan fatis terdiri atas: partikel, kata, dan frase; dari unsur kebahasaannya berasal dari bahasa Indonesia dialek Betawi, bahasa asing (Inggris, Arab, dan Jepang), dan bahasa daerah (Jawa dan Sunda).

Penelitian lain yang dilakukan oleh Hasnah Faizah AR (2013) yang berjudul Kategori Fatis dalam Bahasa Melayu Riau Dialek Kuok menyebutkan temuan penelitian sebagai berikut. Pertama, bentuk fatis meliputi partikel, kata, frasa, paduan fatis, dan gabungan fatis. Kedua, fungsi fatis meliputi mematahkan pembicaraan, pembuktian, pengukuhan, penegasan, menyakinkan, serta memulai dan mengakhiri pembicaraan. Ketiga, makna fatis, antara lain penekanan permintaan, penghalusan sindiran, penekanan penolakan, menyatakan intensitas keadaan, menyatakan kuantitas perbuatan, dan penekanan pengingkaran.

Penelitian lain mengenai ungkapan fatis juga dilakukan oleh Evi Qurniati dalam penelitian yang berjudul Bentuk Fatis Tuturan Guru dalam Interaksi Kelas Bahasa Indonesia. Hasil dari penelitian ini adalah, pertama, bentuk fatis tuturan guru dalam interaksi kelas bahasa Indonesia, meliputi (1) bentuk fatis berupa partikel dong, kok, nah, -lah, -kah, pun, kan, dan sih, (2) bentuk fatis yang berupa kata ayo, halo, dan ya, (3) bentuk fatis berupa frase 'selamat pagi' dan 'selamat siang'. Kedua, (1) fungsi menjaga agar komunikasi tetap berkesinambungan dengan partikel kan, (2) menjaga agar komunikasi tetap berkesinambungan dengan partikel -pun, (3) menjaga agar komunikasi tetap berkesinambungan dengan partikel -lah, (4) menjaga agar komunikasi tetap berkesinambungan dengan partikel sih, (5) menjaga agar komunikasi tetap berkesinambungan dengan partikel lho, (6) menjaga agar komunikasi tetap berkesinambungan dengan partikel deh, (7) menjaga agar komunikasi tetap berkesinambungan dengan partikel kok, (8) menciptakan ikatan sosial yang harmonis dengan partikel dong, (9) menjaga agar komunikasi tetap berkesinambungan dengan partikel nah, (10) menjaga agar komunikasi tetap berkesinambungan dengan kata ayo, (11) menjaga agar komunikasi tetap berkesinambungan dengan kata $y a$, (12) memecah kesenyapan dengan kata fatis halo, (13) memulai komunikasi dengan frase 'selamat pagi', (14) mengakhiri komunikasi dengan frase 'selamat siang'. Ketiga, makna fatis tuturan guru dalam interaksi kelas bahasa Indoensia, meliputi (1) menekankan pembuktian, (2) menonjolkan kata yang dilekati, (3) sebagai penguat dalam sebutan dan makna imperatif, (4) menekankan pertanyaan, menyatakan kekagetan, (6) memberi persetujuan dan penguat sebutan dalam kalimat, (7) menekankan 
maksud penutur dan mempunyai arti mengapa, (8) menghaluskan perintah, (9) minta supaya kawan bicara mengalihkan perhatian ke hal lain, (10) menekankan ajakan,

mengukuhkan apa yang ditanyakan kawan bicara dan meminta persetujuan atau pendapat, (12) menyapa atau menyalami mitra tutur.

\section{Metode Penelitian}

Desain penelitian secara garis besar dapat diuraikan sebagai berikut.

1. Tahap persiapan untuk mengidentifikasi masalah dan pencarian studi pustaka khususnya dengan referensi jurnal penelitian sebelumnya.

2. Setelah masalah teridentifikasi dan literatur yang relevan ditemukan, tahap berikutnya mulai mengadakan pengumpulan data dengan cara simak bebas, libat, dan catat. Objek yang diamati adalah tindak tutur yang berimplikasi pada ungkapan fatis dalam masyarakat Jawa, khususnya di wilayah Surakarta, yang meliputi Klaten, Sukoharjo, Boyolali, dan Sragen.

3. Setelah terkumpul data-data yang diperlukan, lalu diolah dan dijadikan dasar untuk pelaksanaan penelitian.

4. Langkah berikutnya adalah pelaksanaan kegiatan yang menunjang dalam penelitian. Kegiatan yang dilakukan adalah mengidentifikasi bentuk-bentuk ungkapan fatis dalam pembuka dan penutup percakapan dalam masyarakat Jawa, khususnya di wilayah Surakarta.

5. Langkah terakhir adalah melakukan evaluasi terhadap hasil pengidentifikasian dan pengklasifikasian untuk mendapatkan kesimpulan akhir.

6. Selama penelitian selalu diadakan diskusi dengan peneliti senior guna menjaga kualitas hasil penelitian.

Secara garis besar, tahapan penelitian ini secara berurutan dan simultan terdiri dari: (1) persiapan, (2) identifikasi masalah dan pencarian artikel jurnal yang relevan, (3) penelitian lapangan, (4) pengumpulan data, (5) analisis, dan (6) hasil penelitian dan penarikan kesimpulan.

Penelitian ini dilakukan melalui penelitian lapangan dengan metode yang digunakan adalah metode simak bebas, libat, dan catat. Metode simak adalah metode yang digunakan untuk memperoleh data dengan menyimak penggunaan ungkapan fatis dalam pembuka dan penutup percakapa. Istilah menyimak tidak hanya berkaitan dengan penggunaan bahasa secara lisan, tetapi juga penggunaan bahasa secara tertulis (Mahsun 2007, 90).

Teknik analisis yang digunakan dalam penelitian ini adalah teknik yang bersifat deskriptif-kualitatif, yaitu dengan mendeskripsikan dan menjelaskan hasil temuan di lapangan, yaitu bentuk-bentuk ungkapan fatis pembuka dan penutup percakapan dalam masyarakat Jawa di wilayah Surakarta.

Penulis memosisikan diri sebagai peserta dalam percakapan dengan narasumber yang tinggal di wilayah Surakarta dan semuanya berlatar belakang suku Jawa.

Secara garis besar metodologi penelitian yang ditempuh meliputi: (1) simak, libat, dan catat, (2) analisis /interpretasi, (3) hasil penelitian.

\section{HASIL DAN PEMBAHASAN}

\section{Ungkapan Fatis dan Contoh Penggunaannya}

\section{Ungkapan fatis sugeng rawuh}

Dalam masyarakat Jawa, ungkapan sugeng rawuh yang artinya "selamat datang" digunakan untuk membuka percakapan dalam situasi formal atau resmi. Ungkapan ini termasuk ungkapan fatis sebagai ungkapan sambutan terhadap kedatangan tamu undangan atau kehormatan. Biasanya, 
ungkapan ini digunakan ketika berpidato atau dalam acara resmi.

Contoh:

Katur dhumateng tamu undangan sedaya ingkah sampun rawuh sedaya, kawula pinangka wakil saking keluarga ageng Bapak Suyatno ngaturaken sugeng rawuh dhumateng panjenengan sami.

(Kepada para tamu undangan yang sudah hadir di sini, saya sebagai wakil dari keluarga besar Bapak Suyatno mengucapkan selamat datang kepada Anda semua)

Konteks pada contoh di atas, penutur merupakan pambiwara (pembawa acara) dalam upacara pernikahan di daerah Surakarta. Ia mengucapkan tuturan tersebut kepada para tamu undangan yang baru hadir untuk mempersilakan duduk. Tuturan semacam ini juga sebagai bentuk penghormatan kepada para tamu. Tuturan ini biasanya hanya digunakan dalam peristiwa yang bersifat formal atau resmi dengan latar belakang budaya Jawa dan tidak lazim digunakan dalam situasi sehari-hari yang tidak formal.

Ungkapan fatis kula nuwun dan matur nuwun

Ungkapan fatis kula nuwun biasa digunakan apabila seseorang hendak datang bertamu ke rumah orang lain. Berikut ini contoh ungkapan fatis kula nuwun saat hendak bertamu.

Joko : Kula nuwun, Bu.

Ratna : Mangga, Mas.”

Joko : Pak Endri wonten ndalem, Bu?

Ratna :Oh, wonten. Mangga pinarak mlebet mriki, Mas.

Joko : Nggih, Bu, matur nuwun.

Ratna :Ditengga sekedhap nggih, Mas. Bapakipun nembe siram.

Joko :Oh, nggih, Bu, kula tenggo wonten mriki.

(Joko : Permisi, Bu.

Ratna : Silakan, Mas.

Joko : Pak Endri ada di rumah, Bu?
Ratna : Oh, ada. Ayo, silakan masuk, Mas.

Joko : Ya, Bu, terima kasih.

Ratna : Ditunggu sebentar ya, Mas, Bapak sedang mandi.

Joko : Oh, baik, Bu, saya tunggu di sini saja.)

Konteks percakapan di atas adalah penutur bernama Joko adalah seorang pemuda berusia sekitar 20 tahun, pekerjaan sebagai karyawan di pabrik mebel, tinggal Klaten, bahasa seharihari bahasa Jawa. Mitra tutur bernama Ratna adalah seorang ibu berusia sekitar 40 tahun, pekerjaan sebagai dosen, tinggal di Klaten, bahasa seharihari menggunakan bahasa Jawa dan bahasa Indonesia.

Situasi tutur yang mendukung contoh di atas adalah situasi yang semi resmi. Peserta yang terlibat dalam percakapan di atas adalah dua orang penutur dan mitra tutur yang berbeda usia dan profesi. Tujuan ungkapan fatis kulo nuwun bermakna memberi salam dan meminta izin untuk bertamu dan ungkapan matur nuwun sebagai ungkapan terima kasih atas penawaran yang diberikan dari tuan rumah. Kedua ungkapan fatis tersebut menyiratkan kesantunan yang diucapkan secara langsung oleh penutur kepada mitra tutur.

\section{Ungkapan fatis nyuwun tulung}

Ungkapan fatis nyuwun tulung digunakan sebagai penghalus kalimat perintah. Hal ini senada dengan pendapat Lakoff (dalam Cook, 1989) bahwa dalam proses komunikasi, faktor kesantunan dalam berbicara harus dipatuhi, salah satunya dengan jangan memaksa (don't impose) agar jalinan hubungan social dengan mitra tutur berlangsung dengan baik.

Perhatikan contoh berikut ini.

$\begin{aligned} \text { Nur : } & \text { Mbak, nyuwun tulung } \\ & \text { dipendhetke buku dhuwur } \\ & \text { lemariniku. }\end{aligned}$

Dinar : Njih, Bu. 
$\begin{array}{ll}\text { (Nur : } & \text { Mbak, minta } \\ & \text { diambilkan buku dolong } \\ & \text { lemari itu. }\end{array}$

Dinar : Baik, Bu.)

Konteks pada tuturan di atas terjadi di ruang perpustakaan sebuah kampus swasta di Kota Surakarta. Penutur bernama Nur adalah seorang dosen, perempuan, berumur kira-kira 30 tahun meminta tolong atau memerintah dengan ungkapan fatis nyuwun tulung kepada mitra tutur bernama Dinar selaku petugas perpustakaan, perempuan, berumur 22 tahun.

Tuturan yang dituturkan oleh penutur kepada mitra tutur mengandung maksud untuk memerintah, tetapi penutur menggunakan ungkapan fatis sebagai bentuk kesantunan dengan penanda kesantunan kata 'tolong'.

Ungkapan fatis nyuwun pangapunten sebagai ungkapan permintaan maaf dan sebagai penolakan secara halus

Ungkapan nyuwun pangapunten 'minta maaf' merupalan ungkapan fatis yang biasa digunakan ketika seseorang melakukan kesalahan atau menolak sesuatu.

Berikut ini contoh percakapan yang mengandung ungkapan fatis nyuwun pangapunten sebagai bentuk kesantunan berbahasa yang berarti permintaan maaf atas suatu kesalahan.

Endri: Mas, pripun jahitan kula sampun dados?

Yon : Nyuwun pangapunten, Pak, kalih dinten malih nggih." Kala wingi seminggu sing ngrencangi nembe sakit, dados naming kula piyambak.

Endri: Oh, nggih...mboten napa-napa, Mas.

(Endri: Mas, apa jahitan baju saya sudah jadi?

Yon : Maaf, Pak, sudah hari lagi, ya. Sudah seminggu yang lalu karyawan saya sakit, jadi hanya saya sendiri yang menjahit.

Endri : Oh, ya sudah...tidak apa-apa.)

Konteks tuturan di atas terjadi antara penutur bernama Endri, seorang laki-laki berusia 44 tahun, berprofesi sebagai PNS yang mengorderkan jahitan baju seragam ke mitra tutur bernama Yon, laki-laki berusia 30 tahun, yang berprofesi sebagai penjahit baju khusus pria. Sesuai kesepakatan awal, bahwa Yon menjanjikan kepada Endri bahwa jahitan baju seragamnya bisa selesai dalam waktu dua minggu. Akan tetapi, pada hari yang dijanjikan ternyata jahitan bajunya belum selesai. Yon akhirnya meminta maaf kepada Endri sebagai pelanggan yang sudah dikecewakan.

Tuturan di atas bermaksud untuk menjaga kesantunan di lingkungan masyarakat Jawa yang menggunakan ungkapan fatis nyuwun pangapunten. Meskipun dalam tuturan tersebut terjadi pelanggaran maksim kuantitas, di mana jawaban yang diharapkan penutur bernama Endri sebenarnya adalah 'sudah' atau 'belum'. Akan tetapi, mitra tutur (Yon) memberikan jawaban yang lebih daripada yang diminta oleh Endri yaitu dengan memberikan penjelasan sebagai alasan keterlambatan jadinya jahitan.

Selain bermakna sebagai ungkapan permintaan maaf, nyuwun pangapunten juga bermakna sebuah penolakan. Perhatikan percakapan di bawah ini.

Darsih : Bulik, mangga diunjuk benterane.

Atun : Nyuwun pangapunten, Mbak, kulo biasa putihan mawon.

(Darsih: Bulik, silakan diminum dulu teh panasnya.

Atun : Maaf, Mbak, saya biasa minum air putih.)

Konteks tuturan di atas adalah saat Atun bertandang ke rumah Darsih. Atun dan Darsih adalah pedagang kain di sebuah pasar di Kota Klaten. Saat itu, Atun bertandang ke rumah Darsih 
untuk memesan jenis kain tertentu. Sebagai tuan rumah, Darsih menyuguhkan segelas teh panas kepada tamunya. Sebagai tamu, Atun berucap terima kasih sudah disuguhi minuman. Akan tetapi, demi menjaga kesantunan dan agar tidak menimbulkan ketersinggungan jika teh tersebut tidak diminum, Atun melakukan penolakan dengan menggunakan ungkapan fatis nyuwun pangapunten.

Dalam masyarakat Jawa, sudah menjadi sebuah kebiasaan jika ada tamu yang bertandang ke rumah selalu disuguhi minuman berupa teh yang tentu saja berasa manis dan terhidang dalam kondisi panas. Orang Jawa sering menyebut dengan akronim ginasthel yang artinya legi (manis), panas, dan kenthel (kental). Hal ini sebagai bentuk penghormatan dari tuan rumah kepada tamunya. Sebaliknya, jika menjamu tamu dengan menghidangkan air teh yang tidak berasa manis dan agak bening, atau bahkan hanya menyuguhkan air putih, akan dinilai sebagai tindak yang tidak santun dan tidak menghormati tamu yang datang.

\section{Ungkapan fatis mangga}

Ungkapan mangga sebagai bentuk ungkapan fatis yang bermakna 'silakan' atau 'mari' dan biasanya digunakan sebagai pertanda pembicara menutup percakapan dan akan berpisah atau berpamitan. Perhatikan contoh di bawah ini.

$$
\text { Sri : Mangga, Bu, diunjuk rumiyin }
$$

Ratna : Nggih, Bu, matur nuwun.

(Sri : Silakan, Bu, diminum dulu seadanya.

Ratna : Ya, Bu, terima kasih.)

Konteks pada percakapan di atas menunjukkan bahwa penutur (Sri) mempersilakan kepada tamunya/mitra tutur bernama Ratna yang sedang bertamu di rumah Ibu Sri. Saat itu, Ibu Sri hanya menyuguhkan segelas air teh tanpa suguhan lainnya.
Sebagai bentuk penghormatan kepada tuan rumah yang sudah menyuguhkan segelas teh panas, Ratna mengucapkan terima kasih kepada tuan rumah, yaitu Ibu Sri. Penutur dan mitra tutur dalam percakapan di atas terjadi di wilayah Sukoharjo. Keduanya menggunakan bahasa Jawa dalam komunikasi keseharian. Ibu Sri berumur 50 tahun yang berprofesi sebagai ibu rumah tangga, sedangkan Ratna berumur 42 tahun yang berprofesi sebagai dosen. Antara penutur dan mitra tutur menggunakan sapaan Bu, sebagai bentuk kesantunan dan ungkapan fatis mangga sebagai bentuk penghormatan kepada mitra tutur.

Ungkapan fatis mangga yang berarti 'mari' dapat dilihat pada contoh percakapan di bawah ini.

Ninik : Mangga, Bu, saya nyuwun pamit rumiyin.

Suci : Nggih, mangga, Bu, nderekke.

(Ninik: Mari, Bu, saya pamit dulu.

Suci : Ya, Bu, selamat jalan.)

Ungkapan mangga pada percakapan di atas bermakna 'mari'. Penutur bernama Ninik bermaksud berpamitan kepada mitra tutur bernama Suci untuk mohon izin pulang terlebih dahulu. Konteks situasinya adalah pada suatu acara yang dihadiri oleh keduanya dan saat itu acara masih berlangsung. Dikarenakan ada suatu keperluan, Bu Ninik bermaksud pulang terlebih dahulu dan memohon izin kepada $\mathrm{Bu}$ Suci yang menjadi pemrakarsa acara tersebut.

Ungkapan fatis kados pundi kabaripun?

Ungkapan kados pundi kabaripun? 'bagaimana kabarnya?' termasuk ungkapan fatis yang bermakna bahwa penutur ingin mengetahui kabar dari mitra tutur dan bisa juga bermakna bertanya kepada mitra tutur tentang pendapatnya. Perhatikan contoh percakapan di bawah ini.

(1) Purwanto:Dangu mboten pinanggih, kados pundi kabaripun, $B u$ ? 
(2) Ratna : Pangestunipun, Pak, pinaringan sehat.

(Purwanto : Lama tidak bertemu, bagaimana kabarnya, $\mathrm{Bu}$ ?

Ratna : Alhamdulillah, Pak, senantiasa sehat.)

Perhatikan dengan penggunaan ungkapan fatis kados pundi seperti contoh di bawah ini.

(3) Suci : Kados pundi Bu Ratna biar para dosen itu mau melaksanakan penelitian dan pengabdian? Formula apa yang harus diberikan nggih, $B u$ ?

(4) Ratna : Njih yang pasti memang harus ada penyadaran kagem semua dosen tentang tridharma perguruan tinggi, Bu. Selain itu mungkin saget diparingi punish and reward bagi dosen.

(Suci : Bagaimana Bu Ratna agar para dosen mau melaksanakan penelitian dan pengabdian? Formula apa yang harus diberikan ya, Bu?

Ratna : Ya, yang pasti memang harus ada penyadaran untuk semua dosen tentang tridharma perguruan tinggi, Bu. Selain itu, mungki bisa diberikan punish and reward.)

Ungkapan fatis kados pundi pada percakapan 1-2 dan percakapan 3-4 memiliki makna yang berbeda. Pada percakapan 1, ungkapan fatis kados pundi kabaripun memiliki makna menanyakan kabar, sedangkan ungkapan fatis kados pundi pada percakapan 3-4 memiliki makna menanyakan pendapat atau masukan yang diharapkan dari mitra tutur untuk memberikan saran, masukan, pendapat kepada penutur.
Ungkapan fatis sugeng ... atau wilujeng

Ungkapan sugeng/wilujeng enjang (selamat pagi), sugeng/wilujeng siang (selamat siang), sugeng/wilujeng sonten (selamat sore), dan sugeng/wilujeng dalu (selamat malam) merupakan ungkapan fatis yang bertujuan untuk menyapa mitra tutur berdasarkan waktu saat penutur menyapa mitra tutur. Jadi, ucapan selamat sebagai sapaan bergantung pada waktu, entah pagi, siang, sore, atau malam.

Ungkapan fatis katuran pinarak

Ungkapan katuran pinarak 'silakan mampir' sebagai ungkapan fatis yang digunakan ketika seseorang bertemu dengan teman yang sudah dianggap dekat di jalan dan saat itu hendak berpisah. Situasinya adalah penutur terlebih dahulu sampai di tujuan/tempat tinggalnya, sehingga penutur memiliki gagasan untuk memberikan penawaran kepada mitra tutur untuk singgah di rumahnya.

Perhatikan contoh berikut ini.

Dewi : Katuran pinarak, Bude.

Titik : Yo, Mbak, matur nuwun. Sesuk meneh wae, saiki selak layat.

(Dewi: Silakan mampir, Bude.

Titik : Ya, Mbak, terima kasih. Kapankapan saja, sekarang terburuburu mau melayat.)

Konteks pada percakapan tersebut adalah penutur bernama Dewi, perempuan berusia 30 tahun, pekerjaan marketing, bahasa sehari-hari bahasa Jawa sedang bertutur dengan mitra tutur bernama Titik, perempuan, berusia 58 tahun, profesi ibu rumah tangga. Hubungan antara penutur dan mitra tutur sangat dekat dan masih keluarga dekat. Berdasarkan jarak sosialnya, penutur bernama Dewi lebih rendah karena ia berusia lebih muda daripada mitra tutur bernama Titik. Dalam bahasa Jawa, penggunaan tingkat tutur dari yang lebih tua ke mitra tutur yang lebih muda adalah menggunakan bahasa Jawa ngoko. 
Akan tetapi, tingkat tutur yang lebih rendah bertutur ke mitra tutur yang lebih tua usianya, menggunakan bahasa Jawa krama sebagai bentuk kesantunan.

\section{Ungkapan fatis ndherek bingah}

Ungkapan ndherek bingah ikut berbahagia'/'ikut senang' merupakan ungkapan fatis yang ditujukan kepada mitra tutur sebagai bentuk simpati dan ucapan atas kebahagian atau keberhasian yang dicapai oleh mitra tutur.

Perhatikan contoh percakapan di bawah ini.

Sri : Ndherek bingah, Om. Sampun kondur saking tindak Mekah kanti slamet, mugi dados haji ingkang mabrur.

Joko : Ya, amin. Matur nuwun, Budhe.

(Sri : Ikut senang (bahagia), Om. Sudah pulang dari Mekah dengan selamat, semoga menyandang gelar haji mabrur.

Joko : Ya, amin. Makasih, Budhe.)

Konteks tuturan di atas dituturkan oleh Sri, seorang wanita berumur 60-an tahu, pekerjaan ibu rumah tangga, tinggal di Klaten, sehari-hari menggunakan bahasa Jawa. Penutur bernama Joko, seorang laki-laki berumur 55 tahun, pekerjaan guru SMP, tinggal di Klaten, sehari-hari menggunakan bahasa Jawa dan Bahasa Indonesia. Antara penutur Sri dan penutur Joko, keduanya adalah saudara kandung. Sri sebagai kakak perempuan kandung dari penutur Joko.

Dalam masyarakat Jawa, ditemui adanya penggunaan kata sapaan yang seharusnya digunakan oleh anaknya. Seperti dalam contoh di atas, seharusnya penutur Sri menyapa Joko dengan sebutan Dik, sedangkan penutur Joko menyapa Sri dengan sebutan Mbak (sebutan kakak perempuan di Jawa). Akan tetapi, keduanya menggunakan sapaan $\mathrm{Om}$ dan Bude, yang semestinya kedua sapaan tersebut digunakan oleh para anak dari penutur Joko dan Sri. Hal seperti ini sudah lazim pada masyarakat Jawa, khususnya di wilayah Surakarta.

Peristiwa tutur di atas terjadi saat Sri menyambut Joko dari kepulangannya menunaikan ibadah haji di Tanah Suci tahun 2016.

Berdasarkan teori kesantunan Leech, percakapan antara Sri dan Joko di atas mematuhi maksim penerimaan karena penutur Sri memberikan pujian dan mendoakan agar Joko mendapat gelar haji mabrur.

Ungkapan fatis ndherek belasungkawa

Ungkapan ndherek belasungkawa 'ikut berduka cita' merupakan jenis ungkapan fatis yang biasa digunakan oleh masyarakat Jawa, pada khususnya, dan masyarakat Indonesia pada umumnya. Ungkapan ndherek belasungkawa ini ditujukan kepada mitra tutur yang sedang mengalami musibah atau bencana dan sebagai tanda rasa simpati dari penutur kepada mitra tutur atas musibah atau bencana yang sedang dialaminya.

Bentuk simpati ini menurut teori kesantunan Leech merupakan bentuk pematuhan pada maksim simpati. Maksim jenis ini menyarakan kepada penutur agar memaksimalkan simpati dan meminimalkan antipati. Artinya, apabila mitra tutur sedang mengalami peristiwa duka, penutur wajib menanggapinya dengan rasa simpati.

Perhatikan contoh berikut ini.

Ratna : Selamat siang, Prof.

Prof Diro : Siang. Ada kuliah apa?

Ratna : Kuliahnya, Prof Edi, Prof.

Prof Diro: Oh, ya... ya... Ini semester berapa to?

Ratna : Saya sekarang semester dua, Prof.

Prof Diro: Oke... oke... Ohya, sudah tahu kabar saya belum?

Ratna : Kabar apa njih, Prof?

Prof Diro: Istri saya kan sebulan yang lalu meninggal dunia.

Ratna : Innalillahi wa innailaihi rajiun. Oh, ya. Mohon maaf Prof. Saya tidak mendengar kabar dukanya. Ndherek 
belasungkawa njih, Prof, semoga ibu seda dengan khusnul khatimah. Aamiin.

Prof Diro: Ya... ya... ya... Makasih doanya.

\section{Bentuk-bentuk Ungkapan Fatis}

Berdasarkan hasil penelitian yang telah dilakukan oleh peneliti dengan mengadakan penyimakan atas percakapan yang terjadi di masyarakat Surakarta didapati beberapa ungkapan fatis yang digunakan oleh masyarakat Jawa, khususnya di wilayah Surakarta, sebagai pembuka dan penutup percakapan dapat dilihat secara ringkas pada uraian berikut ini:

1. sugeng rawuh

Penggunaan: dalam pembuka percakapan ketika penutur menyambut mitra tutur sebagai tamu atau sebagai undangan dari penutur.

Makna: ungkapan penghormatan selamat datang/sambutan terhadap kedatangan tamu undangan atau tamu kehormatan

2. kulonuwun

Penggunaan: untuk membuka percakapan ketika bertamu ke rumah orang lain.

Makna: memberi salam dan meminta izin untuk bertamu.

3. matur nuwun

Penggunaan: untuk menutup percakapan sebagai bentuk ucapan terima kasih kepada mitra tutur yang telah memberikan sesuatu, baik benda maupun jasa.

Makna: sebagai ungkapan terima kasih atas penawaran yang diberikan dari tuan rumah.

4. nyuwun tulung

Penggunaan: untuk meminta kesediaan mitra tutur agar berkenan memberi bantuan/ menolong.

Makna: penghalus perintah.

5. nyuwun pangapunten

Penggunaan: ketika penutur melakukan kesalahan atau penutur ingin menolak sesuatu atas ajakan atau perintah mitra tutur.

Makna: permintaan maaf dan penolakan secara santun.

6. mangga

Penggunaan: sebagai pertanda penutur ingin menutup percakapan dan akan berpisah atau berpamitan. Makna: ungkapan untuk mempersilakan mitra tutur.

7. kados pundi

Penggunaan: untuk mengetahui kabar dari mitra tutur atau bertanya pendapat.

Makna: menanyakan kabar atau keadaan.

8. sugeng .... / wilujeng ....

Penggunaan: untuk menyapa mitra tutur berdasarkan waktu saat penutur menyapa mitra tutur. Makna: menyatakan salam berdasarkan waktu kejadian.

9. katuran pinarak

Penggunaan: ketika penutur ingin mempersilakan mitra tutur bertandang/singgah ke rumahnya. Makna: ungkapan penawaran.

10. nderek bingah

Penggunaan: untuk mitra tutur sebagai bentuk simpati atas kebahagiaan atau keberhasilan yang dicapai mitra tutur.

Makna: ungkapan simpati ikut senang atas peristiwa yang dialami mitra tutur.

11. nderek belasungkawa

Penggunaan: untuk mitra tutur yang sedang mengalami musibah/bencana dan sebagai tanda simpati.

Makna: ungkapan simpati ikut berduka cita atas peristiwa yang dialami mitra tutur.

\section{KESIMPULAN}

Dalam masyarakat Jawa, khususnya di wilayah Surakarta, dalam berinteraksi antarsesama banyak ditemukan berbagai ungkapan fatis. Ungkapan fatis ini bertujuan untuk menjaga keharmonisan dalam masyarakat, meskipun dalam 
kenyataannnya ada beberapa yang digunakan sekadar untuk berbasa-basi. Namun, tujuan utama adalah sebagai bentuk kesantunan dan penghormatan dari penutur yang ditujukan untuk mitra tutur demi menjalin keharmonisan dalam hubungan di masyarakat.

Beberapa ungkapan fatis yang banyak digunakan oleh masyarakat Jawa, khususnya di wilayah Surakarta, antara lain ungkapan fatis sugeng rawuh, kulo nuwun, matur nuwun, nyuwun tulung, nyuwun pangapunten, monggo, kados pundi, sugeng ..., wilujeng ..., katuran pinarak, nderek bingah, dan nderek belasungkawa.

Variasi penggunaan bentuk-bentuk ungkapan fatis ini bertujuan untuk memulai percakapan, meminta izin, memperhalus perintah, berterima kasih, penolakan secara halus, ucapan simpati, dan meminta maaf. Berdasarkan ungkapan fatis tersebut diketahui karakter masyarakat Jawa yang menghargai dan menghormati mitra tuturnya dengan menggunakan ungkapan fatis sebagai bentuk kesantunan berbahasa.

\section{Daftar Pustaka}

Antariksa. 2009. Kearifan Lokal dalam Arsitektur Perkotaan dan Lingkungan Binaan

$<$ http://antariksaarticle.blogspot.com/20 09/08/kearifan-lokal-dalam-arsitektur. html > diunduh 1 April 2015.

Chaer, Abdul. 2012. Kesantunan Berbahasa. Jakarta: Rineka Cipta

Jacobson, N \& J Gottman 2004. "Basic Fact About Batting: Myths vs Reality". dalam. S. Coltrane. Families and
Society: Classic and Contemporary Reading. Canada: Wadsworth

Kridalaksana, Harimurti. 2000. Kelas Kata dalam Bahasa Indonesia. Jakarta: Gramedia

Mahsun. 2007. Metode Penelitian Bahasa, Tahapan Strategi, Metode, dan Tekniknya. Jakarta: PT Raja Grafindo Persada

Malinowski, B. 1993. "The Problem of Meaning in Primitive Languages" dalam Odgen dan Richard. The Meaning of Meaning. London: Routledge \& Keegan Paul Ltd.

Poespowardojo, Soebagjo, 1986. "Pengertian Local Genius dan Relevansinya dalam Modernisasi”. dalam Ayatroheadi (ed) 1986. Kepribadian Budaya Bangsa. Jakarta: Pustaka Jaya

Pranowo. 2009. Kesantunan Berbahasa Tokoh Masyarakat (Pidato Penyuluhan Guru Besar FKIP Universitas Sanata Dharma). Yogyakarta: Universitas Sanata Dharma

Rahardi, Kunjana. 2008. Pragmatik: Kesantunan Imperatif Bahasa Indonesia. Jakarta: PT Erlangga

Sugihastuti. 2007. Editor Bahasa. Yogyakarta: Pustaka Pelajar

Surakhmad, Winarno, 2002. Metode dan Teknik Research: Pengantar Metodologi Ilmiah. Bandung: CV Tarsito

Suryabrata, Sumadi. 2014. Metode Penelitian. Jakarta: Raja Grafindo Persada

Tarigan, Henry Guntur. 1990. Pengajaran Pragmatik. Bandung: Angkasa.

Widyastuti, Hesti. 2013. "Santun dalam Berbahasa" dalam Jurnal Ilmiah Kebahasaan Jalabahasa. 9 (2)

Wijana, I Dewa Putu \& Muhammad Rohmadi,. 2006. Sosiolinguistik, Kajian Teori dan Analisis. Yogyakarta: Pustaka Pelajar 